\title{
The Research Framework of the New Energy Companies Increase the Efficiency
}

\author{
Shihong Zeng \\ economics \& management school \\ Beijing university of technology \\ Beijing, China \\ zengshihong2000@aliyun.com
}

\author{
Chen Ma \\ economics \& management school \\ Beijing university of technology \\ Beijing, China \\ 543110012@qq.com
}

\begin{abstract}
The paper introduces the needs of China developing new energy. The new energy industry is likely to become the engine of the new round of industrial revolution, which is mainly due to new energy accords with human aspirations on reducing excessive consumption of resources and protecting environment of the Earth. Then the paper reviewed the literature of new energy industry financing. At last, the research selected research appropriate framework and model variable for further study.
\end{abstract}

Keywords- research framework; new energy; companies; efficiency

\section{INTRODUCTION}

The China State Council decision on speeding up the cultivation and development of strategic emerging industries (national, 2010) [1] which mentions that strategic emerging industry plays an important role for guiding the development of future economy and society. Developing strategic emerging industries have become a significant strategy for the world's leading countries to seize the new round of economy and the high point of scientific and technical development. China is at a pivotal period in the overall construction of a well-off society, which we must follow the requirement of the scientific outlook on development, seize the opportunity, catch a clear direction, highlight the focus and speed up cultivating and developing strategic emerging industries.

Strategic emerging industry is a kind of industry, which is based on significant technological breakthroughs and major development demand and has an important influence on guiding global and long-term social and economic development, knowledge-intensive technology, low consumption of material resources, great growth potential and good comprehensive benefit. Speeding up the cultivation and development of strategic industry is of great strategic importance on promoting China's construction of modernization, which is the essential choice of China's economic development, especially in the later period of the financial crisis. As China faces such problems, for instance, increased pressure on economic growth, the constraints of resource environment becoming more obvious, the highlight pressures of science and technology, we need to depend on strategic industries to achieve leap-forward development. (Fu Guangjun 2011)[2] We need for a sound financial policy support system, and step up efforts to support and guide and encourage social investment to speed up the cultivation and development of strategic industry.

China needs to develop new energy and other strategic emerging industries in order to change the way of economic growth. According to the stage of development and feature of strategic emerging industry, there are such industries as key industries in the development, which are energy saving and environmental protection industry, new-generation information technology industry, biology industry, high-end equipment manufacture industry, new energy industry, new materials industry and new energy automobile industry. We require creating a good international environment which advantages the development of strategic emerging industries, increasing the degree of promoting support, perfecting the supporting system, and taking active use of financial support of fiscal policy. The efficiency of financial support for strategic industry determines the degree of industrial prosperity.

National Development and Reform Commission and the Ministry of Finance started "national strategic emerging industries venture capital investment plan" in the end of October, 2009. The scale of the first venture capital investment plan is up to 9.2 billion RMB, which is to support strategic emerging industries development. On December 23, 2009, four agencies (that is, People's Bank of China, China Banking Regulatory commission, China Securities Regulatory Commission and China Insurance Regulatory Commission these four financial management and oversight sectors) also have published 'on further do financial service support on major industries' adjustment revitalization and inhibition part industry capacity excess of guide views', which not only reduced the traditional industries with excess capacity but also gave more financial support to strategic emerging industries.

The changes of national policy on strategic industries guide industrial structure adjustment to exchange directly, and we can use the following figure to reflect.

This paper focuses on the perfection of China's development of strategic emerging industries---new energy industries. The reason why all of countries place great hopes in the new energy industry is that it is considered most likely to become the engine of the new round of industrial revolution, which is mainly due to new energy accords with human aspirations on reducing excessive consumption of resources and protecting environment of the Earth, and new energy can improve the human's productive way and also new energy can form a long chain to create more employment opportunities.

This paper takes use of DEA model to study the financing efficiency of chinese listed companies of new energy industry and its influencing factors in East, central and West areas of China, which primarily focuses on the contribution of equity and debt financing in emerging strategic industries' growth.

We collect quarterly data from this period of time, 2007 2011, when financial crisis erupts, and measure the different areas of strategic emerging industry's efficiency of financial support of sample listed companies, which represent by the 
new energy industry, meanwhile we analyze comparatively the discrepancies among different regions.Then we use DEA efficiency measure result as the dependent variable to further develop the VAR model and analyze the factors of affecting the efficiency of the financial support in strategic industries, which we major study on the role of debt financing and equity financing and ensure to strike a positive effective policy recommendations based on the results.

\section{LITERATURE REVIEW}

First, Relative to the comparison of Government fiscal policy and fiscal policies to encourage the guidance of investment funds, there are relatively few literatures on financial markets participating to support strategic emerging industry independently, and equity and debt financing continues to be encouraged by Government policies. A large number literature abstractly discuss equity financing contributions of financial support to strategic industries growth, which use less empirical analysis and involve less debt financing.

Liu Zhibiao (2011) [4] think that we should encourage commercial banks to control risk and early layout as principles, to construction and perfect its technology Bank features (technology franchise institutions) as breakthrough, at the same time, we should increase credit inputs, adjust credit structure, and speed up technology financial products and innovation of service. Achieving to change the development of economic support, meanwhile, we should establish commercial banks as bellwhether in technological finance. Wang Lin (2011) [5] think that compared to traditional industries, strategic emerging industry excits differences in some aspects,like technical risks and policy risks, so that commercial banks should take effective measures to grasp the various types of risks in the development of strategic industries, and promote Chinese economic transition and industrial structure updating better. Xiao Bin and Li Haibo (2011) [6] think that from these two perspectives on industrial development cycle and industry chain, we need to research on how to classfy the choice of financing mode in emerging industries. Discussion on the opportunities and challenges of strategic industries bringing to commercial banks, and putting forward specific policy recommendations from multiple aspects on commercial banks how to seize opportunities, meet challenges and strengthen support to emerging strategic industries.

Xiong Zhengde and Lin Xue (2010) [7] apply DEA method on the empirical research, which shows that marketablity financial support action lacks efficiency in period of economic fluctuations, and the realization of financial support efficiency accompanys the increasing risk, and direct finance becomes the main support for strategic industries development, in the circumstances of indirect financing driving force lack. The analysis concludes that we need to give full play to the guiding role of policy finance, highlight the support of banks, promote diversified financial services, and improve the industrial ability to withstand risk to improve the financial support efficiency of strategic emerging industries. Xiong Zhengde, Zhan Bin and Lin Xue (2011) [8] use DEA method to structure the Logit model to analyze the affecting factors of the efficiency. The empirical research has shown that strategic industries development is prodigiously affected by the macroeconomic situation, and the development of emerging industries, which relates to the low-carbon industries, has a strong momentum, and also these three major industries, new-generation information technology, high-end equipment manufacturing and bio-financial support, achieve financing support efficiency having difficulties.Duan Yiqun (2009) [9] builds a model of reflecting the relationship between the domestic financial system and the growth rate of equipment industry, from which analyzes the bank loans and equity financing on capital markets influencing on the growth of the industry.

Berger, a. n., Schaeck, k. (2011) [10] analyze Italy, the United Kingdom, and Germany's data, which find that the reason why we do not support the small and medium business enterprises to use venture capital is whether it's proper for the company's development, not because of borrowing difficultily.

Hellmann, t., Lindsey, 1., Puri, m. (2008) [11] explore bank's role in the venture capital market in the United States, which suggests that the Bank is not just a venture capital firm, but they are seeking the complementarity between risk capital and lending activities. The authors find that banks engaged in venture capital activity in order to establish borrowing relationships with enterprises later, which can establish early relationships with enterprises using venture capital investment market, and then they can increase the probability of bank loaning to these companies in the future. In this way, bank is more like a strategic investor, who focuses on long-term benefits.

The study on the measure of DEA efficiency is more mature, mainly using DEA efficiency to analyze the problems on regional financial development efficiency, capital market financing efficiency and listed banks' business performance. Liu Fei (2007) [12] applys DEA model to measure regional financial efficiency, the scale of financial efficiency and the relative effectiveness of financial input indicators in China 30 provinces (cities, districts) and in Eastern, Central and Western regions, so as to reveal the regional otherness of financial efficiency.

\section{RESEARCH FRAMEWORK}

Modigliani and Miller (1958) [13] put forward the famous theory "MM theorem" in their classic paper, which is, 'In perfect capital markets (without transaction costs and taxes), the total cost or market value of the capital is independent of the choice of enterprises' financing mode.' In reality, however, there isn't a sound capital market in China, so we need to consider the different contribution rates of enterprises even industrial growth in different financing ways. Ross (1977) [14] introduced asymmetric information in the corporate financing structure, which finds that the increasing of debt ratio to bring out a positive signal and suggests that managers' expectations of future corporate earnings are higher, so that their market value will increase. Therefore, we need to research on the comparison between the following two main financing ways in the empirical analysis, equity financing and debt financing, which are about the otherness of contribution rate in strategic industries.

(A) Equity finance and its efficiency

Generally considered, there is better evaluation the future value of listed companies in the stock market and free allocation of equity capital is from inefficient sectors of scarce 
capital flowing to the high efficiency of the sector. But this role has a precondition that is the validity of the stock marke to realize, that is to say, whether stock prices include adequacy and accuracy information.

(B) Debt financing and its efficiency

Under the condition of asymmetric information in markets, bank is a good choice to avoid adverse selection and moral hazard. Debt financing (mainly to bank credit), saves the information costs and transaction costs of both investment and financing, and helps increase the efficiency of transactions. At this stage, however, there is not high efficiency of bank credit in China and also there is problem on asset quality deteriorating (Xiao Jin and Ma Yajun, 2004) [15].

\section{MODEL, VARIABLE}

\section{A. Model Design}

In the late 1970's, Data Envelopment Analysis (DEA) showed up, which has an absolute advantage in dealing with the multiple inputs, particularly in the problem of multi-output capacity. In 1984, based on the original C2R model, we assume that the constant in production function returns to scale, and we can see on the further development of BC2 model. Input-DEA model is that based on the input of technical efficiency, which estimates with the ratio of minimum investment and actual input, under the certain outputs. Or we can say that decision makers' trend of pursuit is the reduction of the input.

Financing efficiency shows that enterprise trys hard with the minimum cost to get funding for development and to support business operations. That's why we use input-oriented BC2 models to do research on financing efficiency. Financing support of listed companies in domestic financial systems is mainly in two aspects. One is equity financing that is directly through the capital markets and the other is debt financing, which use bank loans and issue corporate bonds as the main form. Therefore, this paper focus on investigating the different contributions to strategic industries in financing support efficiency of equity financing and debt financing in eastern, midddle and western region of China.

At the time of investigating on the affecting factors of financing efficiency, we select panel data, and combine unit root test and cointegration test of panel data to research the different rates of contribution to the emerging strategic industries with equity and debt financing in the eastern region.

On the model of variable selection, we use integrated technical efficiency in BC2 as the dependent variable and use the input indicators for corresponding measured by DEA efficiency as explanatory variables to analyze the causal relationship between input indicators and efficiency values in detail, which is a clear way to illustrate the affecting factors of financing support efficiency. We choose logarithm of the variable form to eliminate the heteroscedasticity. Data is analyzed by EVIEWS6.0 software.

Cointegration Analysis model for long-term:

$$
\ln \left(\text { Efficiency }_{i t}\right)=\alpha+\beta_{1} \ln \left(D R_{i t}\right)+\beta_{2} \ln \left(E F_{i t}\right)+\varepsilon_{i t}
$$

\section{B. Variable}

- Input-output Indicator (variable) Options
Based on the above considerations and the predecessor of research results, we select the following variables as input parameters:

(1) Gearing Ratio (DR)

It's an index that measures the ability of company using creditor funding to proceed operational activities, which also reflect the effect of capital structure on financing efficiency.

(2) Ratio of Equity Financing (EF)

It's an index that uses vested in the parent shareholders ' equity/total invested capital to represent equity financing ratio, which reflects the size of raising funds in equity financing of listed companies.

- Indicators for outputs, we have the following choices:

(1) Return on Equity (ROE)

It reflects the profitability of listed companies after financing and it's an important variables in the famous DuPont financial analysis.

(2) Main Business Revenue Iincrease (MBRI)

It reflects the growth of listed companies using equity and debt financing. If we use the index of measuring enterprise development capability as outputs indicators, it can reflect the impact of financing behavior on enterprise performance and scale.

\section{ACKNOWLEDGMENT}

The paper thanks Beijing natural science foundation project: 2013 Beijing low-carbon investment and financing mode and operation simulation (project number: 9132001) ; 2011 annual national social science fund major projects: emerging technology analysis theory method and industrial innovation research(project number: 11 \& ZD140); Beijing philosophy and social sciences planning project in 2011, the project name: Beijing modern manufacturing listed company credit risk research(project number: 11JGB029).

\section{REFERENCES}

[1] The national development and reform commission, The state council on speeding up the decision of the cultivating and developing strategic emerging industries ", (guo fa [2010] no. 32).

[2] Fu Guangjun,Tax and strategic emerging industries,Beijing: China market publishing house. 2011, pp4-9.

[3] Department of ministry of commerce industry, On the guidance to promote the development of internationalization of strategic emerging industries , [2011] no. 310 .

[4] Liu Zhibiao,Technology Banking Functions Construction: Research on Some Critical Problems of Commercial Banks Supporting Strategic Emerging Industries Development, Nanjing academy of social sciences, No. 4, 2011, pp1-7.

[5] Wang Lin. The potential risk of strategic emerging industries and commercial Banks to support studies. Rural financial research, (7), 2011, pp39-42.

[6] XiaoBin, Li Haibo. Commercial Banks to support for the development of strategic emerging industry financial policy research. Rural financial research, (5), 2011, pp53-57.

[7] Xiong Zhengde, Lin Xue, Strategic emerging industry listed company financial support efficiency and its influencing factors research. Journal of economic management, (11), 2010, pp26-33.

[8] Xiong Zheng-de,Zhan Bin,Lin Xue, The Efficiency of Financial Support about Strategic Emerging Industry Based on DEA and Logit Model, Systems Engineering, Vol.29, No.6,2011, pp35-41.

[9] Duan Yiqun, Li dong, Li Lianshui. Financial support effect analysis in the equipment manufacturing industry in China. Studies in Science of Science, 27 (3),2009, pp388-292. 
[10] Berger, A. N., Schaeck, K., Small and Medium-Sized Enterprises, Bank Relationship Strength, and the Use of Venture Capital . Journal of Money, Credit and Banking, Volume 43, Issue 2-3, 2011, pp461-490.

[11] Hellmann, T., Lindsey, L., Puri, M., Building Relationships Early: Banks in Venture Capital. Review of Financial Studies, 21(2), 2008, pp513-541.

[12] Liu Fei, Regional financial efficiency based on DEA evaluation studies . Urban development research, 14 (1), 2007, pp6-9.
[13] Modigliani, F.\& Miller M., The Cost of Capital, Corporation Finance, and the Theory of Investment, American Economic Review, (6), 1958, pp261-297.

[14] Ross,S., the Determination of Financial Structure. The Investment signaling Approach. Bell Journal of Economics, (8), 1977, pp23-40.

[15] XiaoJin, Ma Yajun. Enterprise financing efficiency and theoretical framework, Journal of finance and economics, 2004 (5), 2004, pp337340. 